Research Article

\title{
Repurposing Lesogaberan to Promote Human Islet Cell Survival and $\beta$-Cell Replication
}

\author{
Jide Tian, Hoa Dang, Angela Hu, Willem Xu, and Daniel L. Kaufman \\ Department of Molecular and Medical Pharmacology, University of California, Los Angeles, CA, USA \\ Correspondence should be addressed to Daniel L. Kaufman; dkaufman@mednet.ucla.edu
}

Received 12 May 2017; Accepted 26 July 2017; Published 5 September 2017

Academic Editor: Peter Thule

Copyright @ 2017 Jide Tian et al. This is an open access article distributed under the Creative Commons Attribution License, which permits unrestricted use, distribution, and reproduction in any medium, provided the original work is properly cited.

\begin{abstract}
The activation of $\beta$-cell's $A$ - and $B$-type gamma-aminobutyric acid receptors $\left(\mathrm{GABA}_{\mathrm{A}}\right.$-Rs and $\left.\mathrm{GABA}_{\mathrm{B}}-\mathrm{Rs}\right)$ can promote their survival and replication, and the activation of $\alpha$-cell $\mathrm{GABA}_{\mathrm{A}}$-Rs promotes their conversion into $\beta$-cells. However, GABA and the most clinically applicable GABA-R ligands may be suboptimal for the long-term treatment of diabetes due to their pharmacological properties or potential side-effects on the central nervous system (CNS). Lesogaberan (AZD3355) is a peripherally restricted high-affinity $\mathrm{GABA}_{\mathrm{B}}$-R-specific agonist, originally developed for the treatment of gastroesophageal reflux disease (GERD) that appears to be safe for human use. This study tested the hypothesis that lesogaberan could be repurposed to promote human islet cell survival and $\beta$-cell replication. Treatment with lesogaberan significantly enhanced replication of human islet cells in vitro, which was abrogated by a $\mathrm{GABA}_{\mathrm{B}}-\mathrm{R}$ antagonist. Immunohistochemical analysis of human islets that were grafted into immune-deficient mice revealed that oral treatment with lesogaberan promoted human $\beta$-cell replication and islet cell survival in vivo as effectively as GABA (which activates both $\mathrm{GABA}_{\mathrm{A}}$-Rs and $\mathrm{GABA}_{\mathrm{B}}-\mathrm{Rs}$ ), perhaps because of its more favorable pharmacokinetics. Lesogaberan may be a promising drug candidate for clinical studies of diabetes intervention and islet transplantation.
\end{abstract}

\section{Introduction}

A major goal in diabetes research is to develop agents that can safely promote human $\beta$-cell survival and replication. Most mitogens and growth factors that have been shown to promote rodent $\beta$-cell replication fail to promote human $\beta$-cell replication (reviewed in $[1,2]$ ). $\beta$-Cells have been long known to express the GABA synthetic enzyme glutamic acid decarboxylase (GAD), as well as $\mathrm{GABA}_{\mathrm{A}}-\mathrm{Rs}$ and $\mathrm{GABA}_{B}-$ Rs [3-7]. Although $\mathrm{GABA}_{A}$-Rs and $\mathrm{GABA}_{B}$-Rs share GABA as an agonist, these receptors are encoded by distinct gene families and their activation induces different pathways; $\mathrm{GABA}_{\mathrm{A}}-\mathrm{Rs}$ are fast-acting chloride channels and $\mathrm{GABA}_{\mathrm{B}}-\mathrm{Rs}$ are slow-acting G-protein-coupled receptors [8, 9]. Recently, GABA administration has been shown to protect rodent and human $\beta$-cells from apoptosis and to promote their replication both in vitro and in vivo [10-14]. This response is mediated by both $\mathrm{GABA}_{\mathrm{A}}-\mathrm{R}$ and $\mathrm{GABA}_{\mathrm{B}}-\mathrm{Rs}[10-12,14,15]$.
GABA-mediated enhancement of $\beta$-cell replication did not attenuate after five weeks of GABA treatment and led to an eventual increase in $\beta$-cell mass in a nonautoimmune context [14]. Notably, GABA treatment enhanced $\beta$-cell replication and survival in newly diabetic NOD mice $[11,16,17]$, indicating that GABA-R activation can be beneficial in an autoimmune context even when little $\beta$-cell mass remains.

$\beta$-Cells express $\mathrm{GABA}_{\mathrm{A}}$-Rs and $\mathrm{GABA}_{\mathrm{B}}-\mathrm{Rs}[3,4,7,18,19]$. $\alpha$-Cells express $\mathrm{GABA}_{\mathrm{A}}$-Rs but may not express functional $\mathrm{GABA}_{\mathrm{B}}$-Rs, while PCR detects $\mathrm{GABA}_{\mathrm{B}}-\mathrm{R}$ transcripts in isolated $\alpha$-cells (but not the $\alpha$-cell line $\alpha$-TC9), a $\mathrm{GABA}_{\mathrm{B}}-\mathrm{R}$ agonist failed to modulate any of the tested $\alpha$-cell functions $[3,18-21]$. We are unaware of any evidence of functional $\mathrm{GABA}_{\mathrm{B}}-\mathrm{Rs}$ on $\delta$ or PP islet cells. Very recently, longterm treatment with antimalarial drugs that target gephyrin (a protein that participates in $\mathrm{GABA}_{\mathrm{A}}-\mathrm{R}$ transport to the membrane), or treatment with GABA, was shown to promote islet $\alpha$-cell transdifferentiation into $\beta$-cells [22, 23]. 
This conversion appears to be mediated by $\mathrm{GABA}_{\mathrm{A}}$-Rs [22, 23 ] and not the $G_{A B A_{B}}$-Rs that are the focus of this study.

GABA appears safe for human consumption [24] and its inability to pass through the blood-brain barrier (BBB) avoids potential CNS effects. GABA, however, has a relatively low affinity for its receptors, a fast off-rate (presumably so that neurons can quickly respond to the next stimulus), and a short half-life (about 20 minutes in blood [25]) and therefore may be pharmacologically suboptimal. In the clinic, there are many BBB-permeable drugs that can modulate neuronal GABA-Rs and ameliorate CNS disorders such as seizures, anxiety, and insomnia. Their CNS effects, however, raise concerns about their long-term use for the treatment of diabetes. It would be ideal if peripherally restricted GABA-R agonists that were safe for human use could be repurposed for treating diabetes.

Lesogaberan (AZD3355) is a peripherally restricted $\mathrm{GABA}_{\mathrm{B}}-\mathrm{R}$-specific agonist that was developed for the treatment of GERD [26-28]. It has an $\mathrm{EC}_{50}$ of $9 \mathrm{nM}$ (compared to GABA's $\mathrm{EC}_{50}$ of $160 \mathrm{nM}$ ) and a $K_{i}$ of $5 \mathrm{nM}$ (versus $110 \mathrm{nM}$ for GABA) for $\mathrm{GABA}_{\mathrm{B}}$-Rs [26] and a half-life of about 11 hours in peripheral blood $[29,30]$. While treatment of GERD patients with lesogaberan (oral 60-240 mg twice daily) for up to 28 days in several phase IIb clinical trials did not result in sufficient beneficial effects, there were no treatment-related serious adverse events, suggesting that lesogaberan may be safe for human use [27, 29, 31]. Here, we tested the potential of repurposing lesogaberan to promote human islet cell survival and $\beta$-cell replication. Our findings suggest that targeting $\mathrm{GABA}_{\mathrm{B}}$-Rs can promote human $\beta$-cell replication and islet cell survival to a similar extent as GABA.

\section{Materials and Methods}

2.1. Chemicals. Lesogaberan was supplied by AstraZeneca (London, UK). The development and structure of lesogaberan have been previously described [28]. Saclofen, streptozotocin (STZ), and 5-bromo-2-deoxyuridine (BrdU) were purchased from Sigma Aldrich.

2.2. Islet Cell Proliferation Assay. Fresh human islets were obtained from the Integrated Islet Distribution Program (IIDP). The islets (50-75 IEQ/well) were treated in triplicate with, or without, the indicated dosages of lesogaberan in CMRL medium (0.1\% glucose, Gibco) containing 10\% human AB-type sera (MP Biomedicals, Santa Ana, USA) and $1.5 \mu \mathrm{Ci} / \mathrm{ml}$ of ${ }^{3} \mathrm{H}$-thymidine in the presence or absence of the competitive $\mathrm{GABA}_{\mathrm{B}}-\mathrm{R}$ antagonist saclofen $\left(10^{-4} \mathrm{M}\right)$ for 4 days. Islets cultured in medium alone served as controls. The ${ }^{3} \mathrm{H}$-thymidine uptake in individual wells was measured by $\beta$-counter. Data were analyzed by the proliferation index formula: CPM of experimental wells / CPM of controls.

2.3. Analysis of Human $\beta$-Cell Replication In Vivo. All animal experiments were approved by UCLA's Animal Research Committee. NOD/scid mice were injected intraperitoneally with STZ to induce diabetes and implanted with about 2000 human islets under their kidney capsule. The mice were randomized and treated for 12 days with plain water containing $0.8 \mathrm{mg} / \mathrm{ml}$ of BrdU as the control or water containing the same dose of BrdU and lesogaberan $(0.08 \mathrm{mg} / \mathrm{ml})$ or positive control GABA $(6 \mathrm{mg} / \mathrm{ml})$. At the end of treatment, the percentages of $\mathrm{BrdU}^{+}$insulin ${ }^{+}$and $\mathrm{Ki}^{+} 7^{+}$insulin ${ }^{+} \beta$-cells in at least 2000 islet cells of 10 fields (magnification $\times 400$ ) of each islet graft were determined by immunofluorescence in a blinded manner, as our previous report [12].

2.4. Analysis of Human $\beta$-Cell Apoptosis In Vivo. STZrendered diabetic NOD/scid mice were implanted with about 2000-3000 human islets under their kidney capsule. The mice were randomized and given plain water or water containing lesogaberan $(0.08 \mathrm{mg} / \mathrm{ml})$ or positive control GABA $(6 \mathrm{mg} / \mathrm{ml})$. Forty-eight hours later, the percentages of insulin ${ }^{+}$ $\beta$-cells or TUNEL ${ }^{+}$apoptotic islet cells in total islet cells within the grafts of individual recipients were determined by immunofluorescence in a blinded manner, as in our previous report [12].

2.5. Statistical Analysis. Data are expressed as the mean \pm SEM of individual groups ( $n=4-9$ mice per group) from two separate experiments. The difference among groups was analyzed by ANOVA and post hoc Fisher's least significant difference and the difference between groups was determined Student $t$-test. A $p$ value of $<0.05$ was considered statistically significant.

\section{Results}

3.1. Lesogaberan Enhances Human Islet Cell Proliferation In Vitro. Human islets were treated with lesogaberan over a dose range in the presence, or absence, of the $\mathrm{GABA}_{B}-\mathrm{R}$ competitive antagonist saclofen. The effect of drug treatment on islet cell proliferation was determined by ${ }^{3} \mathrm{H}$-thymidine incorporation. We observed that lesogaberan at $3 \mathrm{nM}$ had a small but nonsignificant promitotic effect, while treatment at higher dosages (10 and $30 \mathrm{nM}$ ) led to a 2-3-fold increase in proliferation relative to that of islets cultured in medium alone (Figure 1). Lesogaberan effects were not dose-dependent at the concentrations tested, and this may reflect its bimodal effect that was noted in some early preclinical GERD studies [26], but was not observed in subsequent clinical studies [27, 29, 31-33]. The promitotic effect of lesogaberan was blocked by saclofen (Figure 1). Hence, activation of $\mathrm{GABA}_{\mathrm{B}}-$ Rs enhanced human islet cell proliferation in vitro.

Since $\beta$-cells may be the only islet cell type that expresses functional $\mathrm{GABA}_{\mathrm{B}}$-Rs and $\alpha$-cell transdifferentiation would require long-term $\mathrm{GABA}_{\mathrm{A}}-\mathrm{R}$ activation and would not involve ${ }^{3} \mathrm{H}$-thymidine incorporation into new DNA, the vast majority of the proliferating islet cells are likely to be $\beta$-cells. That contention, however, requires verification, which we pursued using quantitative immunohistochemical analysis of $\beta$-cells in human xenografts below.

3.2. Oral Lesogaberan Promotes Human $\beta$-Cell Replication In Vivo. Next, we quantitatively assessed lesogaberan's effects on human $\beta$-cell replication in vivo. We implanted $\sim 2000$ human islets under the kidney capsule of STZ-rendered diabetic NOD/scid mice. Islet recipients were provided with 


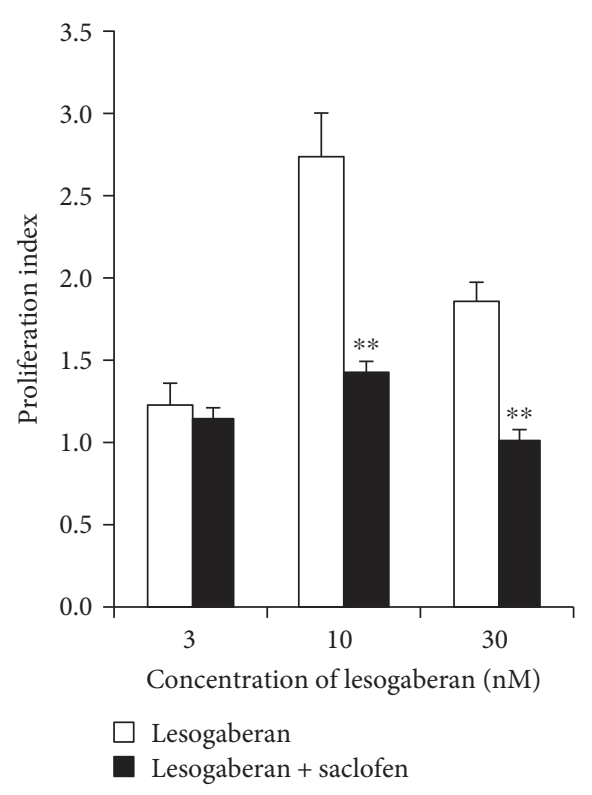

FIGURE 1: Lesogaberan enhances human islet cell proliferation in vitro. Human islets were treated in triplicate with, or without, the indicated dosages of lesogaberan in the presence (black bars) or absence (open bars) of saclofen $\left(10^{-4} \mathrm{M}\right)$ for 4 days. Data shown are the average rate of proliferation \pm SEM relative to that of cultures with medium alone (designated as 1) using islets from two donors, each of which were studied in separate experiments. Treatment with saclofen alone did not affect the proliferation of human islet in our experimental system (data not shown). ${ }^{* *} p<0.01$ versus lesogaberan.

water containing BrdU with, or without, lesogaberan $(0.08 \mathrm{mg} / \mathrm{ml})$ or GABA $(6 \mathrm{mg} / \mathrm{ml})$ for 12 days. The lesogaberan dose was chosen based on the results of previous preclinical studies in GERD models $[26,34]$ and our pilot dosing studies. All islet recipients, including controls given plain water, quickly became normoglycemic after receiving the islet graft and maintained normoglycemia throughout the experimental period. There was no significant difference in their food and water consumption ( $\sim 4 \mathrm{ml} /$ day), as well as body weights among these groups of mice (data not shown).

Immunofluorescent staining indicated that treatment with GABA significantly enhanced human $\beta$-cell replication (Figure 2), similar to previous observations $[14,16]$. Lesogaberan treatment also significantly increased the frequency of $\mathrm{BrdU}^{+}$insulin $^{+}$and $\mathrm{Ki}_{67}^{+}$insulin ${ }^{+}$islet $\beta$-cells relative to that in human islets from the control mice (Figure 2 ). There was no significant difference in the percentages of replicative $\beta$-cells between the lesogaberan-treated and GABA-treated groups of mice. Hence, activation of peripheral $\mathrm{GABA}_{\mathrm{B}}-\mathrm{Rs}$ effectively promotes human islet $\beta$-cell replication in vivo.

\subsection{Oral Lesogaberan Limits Human Islet Cell Apoptosis} following Islet Transplantation. Following human islet transplantation, the islets are subjected to hypoxic, metabolic, and inflammatory stressors which cause the apoptosis of a large proportion of islet cells within the first few days after implantation $[35,36]$. We examined the ability of lesogaberan administration to limit islet cell apoptosis in a human islet xenograft model. We implanted STZ-rendered hyperglycemic NOD/ scid mice with human islets under their kidney capsule and placed them on plain water or water containing lesogaberan or positive control GABA. Two days later, their kidneys were removed and tissue sections were stained by TUNEL and anti-insulin antibodies (Figure 3). In comparison with mice given plain water, treatment with GABA significantly protected human islet cells from apoptosis, consistent with previous observations $[14,16]$. Furthermore, oral feeding with lesogaberan significantly reduced the percentages of apoptotic islet cells (Figure 3(b)) and increased the frequency of insulin ${ }^{+} \beta$-cells in human islet grafts (Figure $3(\mathrm{c})$ ). Thus, lesogaberan-mediated activation of $\mathrm{GABA}_{\mathrm{B}}-\mathrm{Rs}$ limits islet cell apoptosis in transplanted human islets, consistent with previous islet cell survival studies with the prototypic $G_{A B A}-R-$ specific agonist baclofen, a drug unsuited for long-term human use $[10,12,14]$.

\section{Discussion}

The modulation of GABA-Rs on $\beta$-cells is emerging as a new strategy to help promote human $\beta$-cell survival and replication in the context of T1D. Although GABA is safe for human consumption, its pharmacokinetics may be suboptimal. There are a number of available drugs that have been in wide clinical use to modulate GABA-Rs on CNS neurons; however, their CNS effects raise concerns for long-term diabetes treatment. We chose to test lesogaberan's potential for diabetes treatment based on (1) its high affinity for $\mathrm{GABA}_{\mathrm{B}}-\mathrm{Rs}$, (2) its peripheral restriction circumvents CNS effects, and (3) its apparent safety in early clinical studies.

Our initial studies showed that lesogaberan at low dosages (30 and $10 \mathrm{nM}$ ) increased human islet cell proliferation in vitro by about 2-3-fold (resp.). This promitotic effect was abrogated by a $\mathrm{GABA}_{B}-\mathrm{R}$ antagonist, confirming that the effect was mediated through $\mathrm{GABA}_{\mathrm{B}}$-Rs. The proliferating islet cells are likely to be primarily $\beta$-cells because $\beta$-cells may be the only islet cell type that express functional $\mathrm{GABA}_{\mathrm{B}}-\mathrm{Rs}$ and $\alpha$-cell transdifferentiation requires longterm $\mathrm{GABA}_{\mathrm{A}}-\mathrm{R}$ activation [22].

After implanting human islets into scid mice, lesogaberan significantly increased $\beta$-cell replication in the islet grafts. The level of lesogaberan-induced $\beta$-cell replication in vivo was similar to that induced by GABA at the dosages used in our model and similar to the maximum level of $\beta$-cell replication that takes place shortly after birth in humans [37]. The activation of $\beta$-cell $\mathrm{GABA}_{\mathrm{B}}$-Rs causes the opening of potassium channels, release of $\mathrm{Ca}^{+}$from intracellular storage, PKA activation, and $\mathrm{Ca}^{2+}$-dependent activation of PI3K-Akt and CREB (reviewed in [14]). It is notable that lesogaberan promoted $\beta$-cell replication as effectively as GABA (which activates both $\mathrm{GABA}_{\mathrm{B}}$-Rs and $\mathrm{GABA}_{\mathrm{A}}$-Rs) which may be due to its superior pharmacokinetics. Our short-term treatments with lesogaberan and GABA should not have induced $\alpha$-cell transdifferentiation (which became detectable after 2 months of $\mathrm{GABA}_{\mathrm{A}}-\mathrm{R}$ activation $[22,23]$ ), and the small increase they induced in $\beta$-cell replication should not alter islet size. Finally, we observed that 
Anti-BrdU

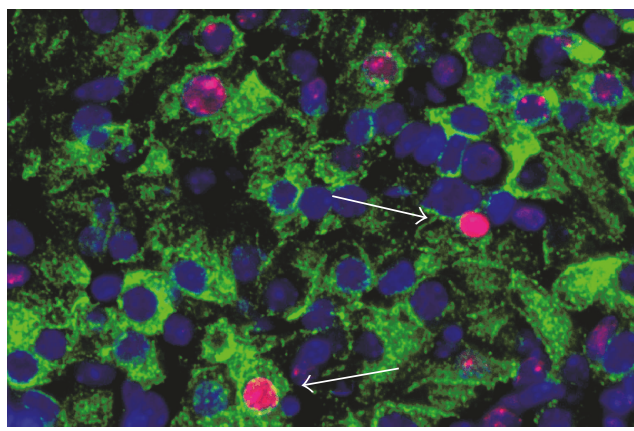

(a)

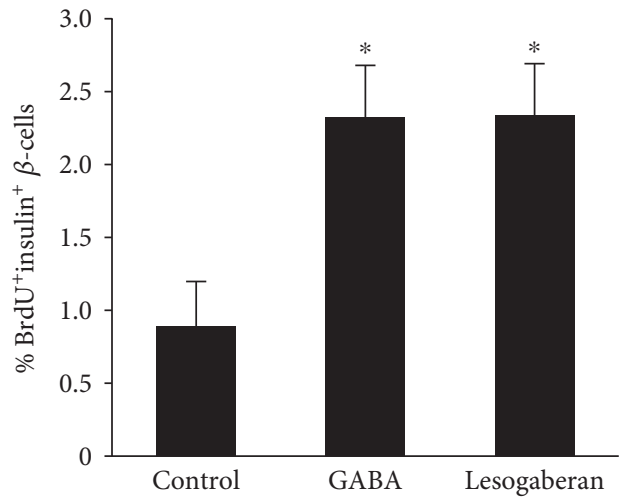

(c)

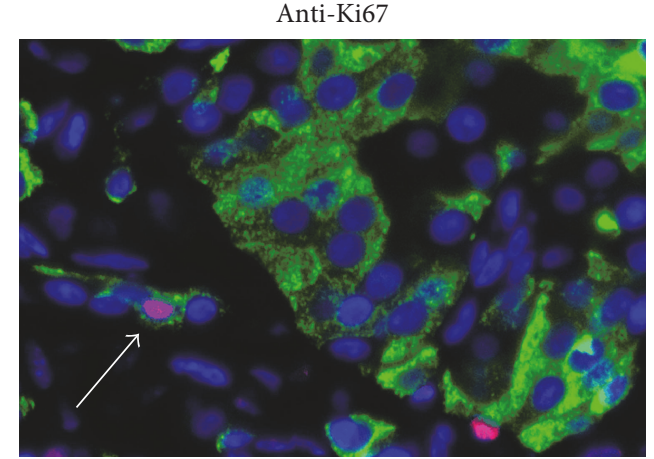

(b)

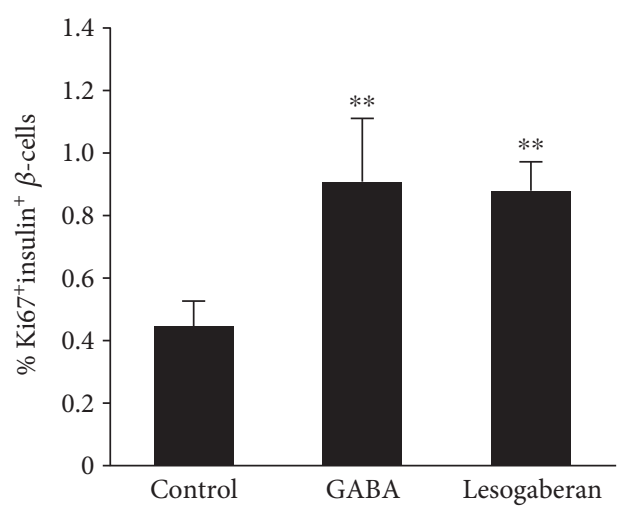

(d)

FIGURE 2: Oral lesogaberan promotes human islet $\beta$-cell replication in mice. Mildly hyperglycemic NOD/scid mice were transplanted with human islets under their kidney capsule. The mice were randomized and provided with water containing with BrdU, with or without GABA $(6 \mathrm{mg} / \mathrm{ml})$ or lesogaberan $(0.08 \mathrm{mg} / \mathrm{ml})$ for 12 days. The percentages of replicated $\beta$-cells were determined by immunofluorescent assays using anti-insulin and anti-BrdU or anti-Ki67, followed by counterstaining with DAPI. (a) Representative image of islet cells (magnification $\times 400)$ costained with anti-insulin (green) and anti-BrdU (red) (arrows). (b) Representative image of islet cells costained with anti-insulin (green) and anti-Ki67 (red) (arrows). (c) Graphical representation of the percentages of BrdU ${ }^{+}$insulin ${ }^{+} \beta$-cells and (d) $\mathrm{Ki}^{+} \mathrm{insulin}^{+}$islet cells in total insulin ${ }^{+} \beta$-cells. Data are mean \pm SEM from two independent experiments, each using islets from a human donor that were implanted into 4-9 NOD/scid mice. The percentages of $\mathrm{BrdU}^{+}$insulin ${ }^{+}$and $\mathrm{Ki}^{+} 7^{+}$insulin ${ }^{+} \beta$-cells in at least 2000 islet cells of 10 fields of each islet graft were determined as described in Materials and Methods. ${ }^{*} p<0.05,{ }^{* *} p<0.01$ versus the control.

lesogaberan treatment significantly preserved human islet cells from apoptosis in human islet grafts.

It is thought that the amount of residual $\beta$-cell mass following T1D onset is a major factor determining the success of interventive therapy such that even a short-term treatment with lesogaberan may help preserve residual $\beta$-cell mass and thereby improve the outcome of interventive therapies. Indeed, GABA treatment enhanced $\beta$-cell replication and survival in newly diabetic NOD mice $[11,16]$, demonstrating that GABA-R activation can be beneficial in an autoimmune context even when there is little residual $\beta$-cell mass. It is worth noting that using FDA guidelines for scaling mouse doses to the equivalent human dosage (http://www. fda.gov/downloads/Drugs/.../Guidances/UCM078932.pdf), the lesogaberan dose we used was about 2- to 7-fold lower than the doses used in phase IIb GERD clinical trials $[27,32,33]$. This suggests that it may be possible to use lower dosage lesogaberan for diabetes treatment.

Conceivably, long-term lesogaberan treatment may lead to increased $\beta$-cell mass in T1D patients if autoimmune responses can be sufficiently controlled. In regard to controlling $\beta$-cell autoimmunity, recent studies indicate that activation of $\mathrm{GABA}_{\mathrm{B}}$-Rs on immune cells has antiinflammatory effects and can ameliorate collagen-induced arthritis and contact dermatitis in mouse models [38, 39]. Therefore, lesogaberan may also have anti-inflammatory effects that help control the pathogenic autoreactive T-cell responses that mediate $\beta$-cell destruction in T1D. It will be of interest to further investigate how activation of $\mathrm{GABA}_{\mathrm{B}}$-Rs modulates the functions of different types of immunocompetent cells, and this may be a fertile area for new anti-inflammatory drug development. Additionally, lesogaberan may be combined with other immune modulators to potentially increase therapeutic effects, as was shown by the synergistic effect of combining GABA and antigenspecific immunotherapy to reverse hyperglycemia in newly diabetic NOD mice [16].

\section{Conclusions}

We found that the $\mathrm{GABA}_{\mathrm{B}}-\mathrm{R}$ agonist lesogaberan promoted human islet cell proliferation in vitro, as well as $\beta$-cell 

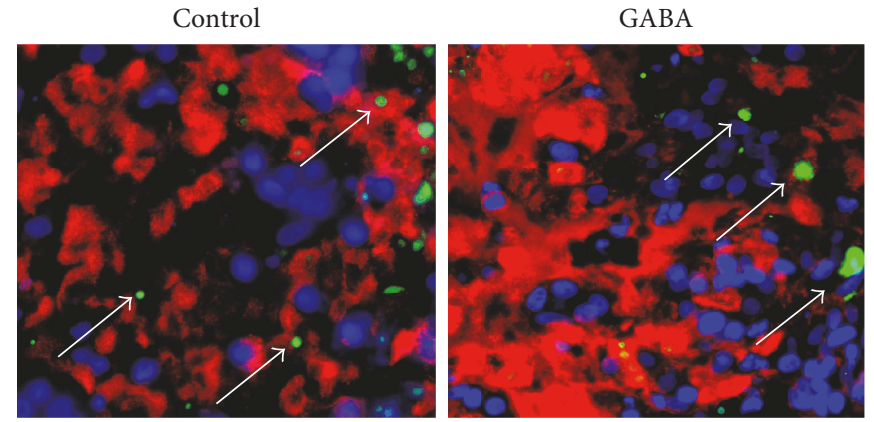

(a)

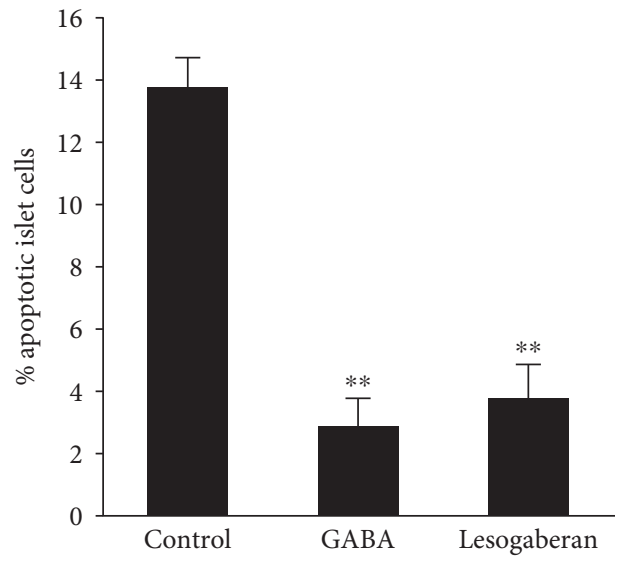

(b)

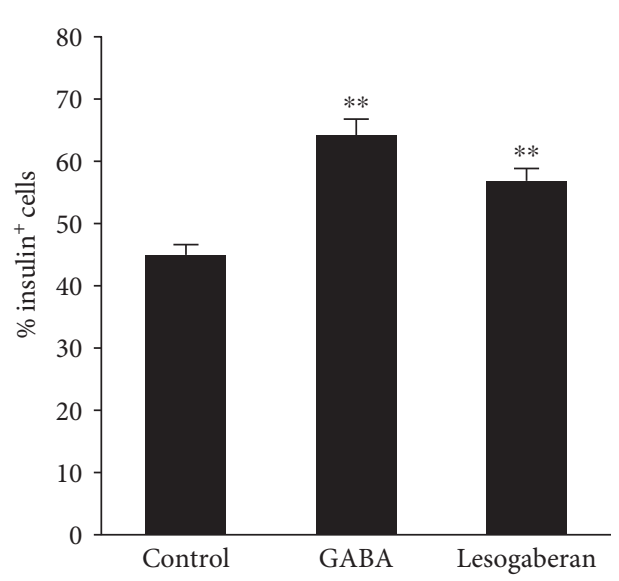

(c)

FIGURE 3: Oral lesogaberan protects human islet $\beta$-cells from apoptosis in islet grafts in mice. Diabetic NOD/scid mice were implanted with human islets and treated with plain water or water containing lesogaberan $(0.08 \mathrm{mg} / \mathrm{ml})$ or GABA $(6 \mathrm{mg} / \mathrm{ml})$ for $48 \mathrm{~h}$. The percentages of apoptotic islet cells and islet $\beta$-cells in total human islet cells were determined by TUNEL assay and costaining with anti-insulin as well as DAPI. At least 2000 human islet cells in 10 fields (magnification $\times 400$ ) from individual grafts were counted. Data are representative image or expressed as the mean $\% \pm$ SEM for each group of mice $(n=5-7)$ from three separate experiments.(a) A representative image with white arrows indicating TUNEL ${ }^{+}$cells (green for TUNEL ${ }^{+}$, red for anti-insulin ${ }^{+}$, and light blue for DAPI staining). (b) Percent apoptotic islet cells and (c) percent insulin ${ }^{+}$islet cells. ${ }^{* *} p<0.01$ versus the control.

replication and islet cell survival in vivo, as effectively as GABA. Accordingly, $\mathrm{GABA}_{\mathrm{B}}-\mathrm{R}$ agonists may provide a new drug class to help maintain residual $\beta$-cell mass and function after diabetes onset. Our findings also suggest that including lesogaberan in the drug regimen following clinical human islet transplantation for even a brief period may reduce $\beta$-cell loss due to stressors and may thereby reduce the number of islets required to achieve insulin independence. Lesogaberan's apparent safety and pharmacokinetic profile make it an excellent candidate for testing in clinical trials.

\section{Conflicts of Interest}

The authors declare that there is no duality of interest associated with this manuscript.

\section{Acknowledgments}

The authors thank the IIDP for providing isolated human islets. This work was supported by a grant from the JDRF (17-2013-403) and the National Institutes of Health (DK092480) to Daniel L. Kaufman.

\section{References}

[1] S. Bonner-Weir, W. C. Li, L. Ouziel-Yahalom, L. Guo, G. C. Weir, and A. Sharma, " $\beta$-Cell growth and regeneration: replication is only part of the story," Diabetes, vol. 59 , no. 10, pp. 2340-2348, 2010.

[2] R. N. Kulkarni, E. B. Mizrachi, A. G. Ocana, and A. F. Stewart, "Human $\beta$-cell proliferation and intracellular signaling: driving in the dark without a road map," Diabetes, vol. 61, no. 9, pp. 2205-2213, 2012.

[3] P. Rorsman, P. O. Berggren, K. Bokvist et al., "Glucoseinhibition of glucagon secretion involves activation of GABAA-receptor chloride channels," Nature, vol. 341, no. 6239, pp. 233-236, 1989.

[4] M. Braun, R. Ramracheya, M. Bengtsson et al., " $\gamma$-Aminobutyric acid (GABA) is an autocrine excitatory transmitter in human pancreatic $\beta$-cells," Diabetes, vol. 59, no. 7, pp. 1694-1701, 2010.

[5] A. Reetz, M. Solimena, M. Matteoli, F. Folli, K. Takei, and P. De Camilli, "GABA and pancreatic beta-cells: colocalization of glutamic acid decarboxylase (GAD) and GABA with synaptic-like microvesicles suggests their role in GABA storage and secretion," The EMBO Journal, vol. 10, no. 5, pp. 12751284, 1991. 
[6] M. Braun, A. Wendt, B. Birnir et al., "Regulated exocytosis of GABA-containing synaptic-like microvesicles in pancreatic $\beta$-cells," The Journal of General Physiology, vol. 123, no. 3, pp. 191-204, 2004.

[7] J. Taneera, Z. Jin, Y. Jin et al., " $\gamma$-Aminobutyric acid (GABA) signalling in human pancreatic islets is altered in type 2 diabetes," Diabetologia, vol. 55, no. 7, pp. 1985-1994, 2012.

[8] R. W. Olsen and A. J. Tobin, "Molecular biology of GABAA receptors," The FASEB Journal, vol. 4, no. 5, pp. 1469-1480, 1990.

[9] B. Bettler, K. Kaupmann, J. Mosbacher, and M. Gassmann, "Molecular structure and physiological functions of GABA(B) receptors," Physiological Reviews, vol. 84, no. 3, pp. 835-867, 2004.

[10] B. Ligon, J. Yang, S. B. Morin, M. F. Ruberti, and M. L. Steer, "Regulation of pancreatic islet cell survival and replication by $\gamma$-aminobutyric acid," Diabetologia, vol. 50, no. 4, pp. 764773, 2007.

[11] N. Soltani, H. Qiu, M. Aleksic et al., "GABA exerts protective and regenerative effects on islet beta cells and reverses diabetes," Proceedings of the National Academy of Sciences of the United States of America, vol. 108, no. 28, pp. 11692-11697, 2011.

[12] J. Tian, H. Dang, Z. Chen et al., " $\gamma$-Aminobutyric acid regulates both the survival and replication of human $\beta$-cells," Diabetes, vol. 62, no. 11, pp. 3760-3765, 2013.

[13] G. J. Prud'homme, Y. Glinka, C. Hasilo, S. Paraskevas, X. Li, and Q. Wang, "GABA protects human islet cells against the deleterious effects of immunosuppressive drugs and exerts immunoinhibitory effects alone," Transplantation, vol. 96, no. 7, pp. 616-623, 2013.

[14] I. Purwana, J. Zheng, X. Li et al., "GABA promotes human $\beta$-cell proliferation and modulates glucose homeostasis," Diabetes, vol. 63, no. 12, pp. 4197-4205, 2014.

[15] J. Tian, H. Dang, B. Middleton, and D. L. Kaufman, "Clinically applicable GABA receptor positive allosteric modulators promote $\beta$-cell replication," Scientific Reports, vol. 7, no. 1, p. 374, 2017.

[16] J. Tian, H. Dang, A. V. Nguyen, Z. Chen, and D. L. Kaufman, "Combined therapy with GABA and proinsulin/alum acts synergistically to restore long-term normoglycemia by modulating T-cell autoimmunity and promoting $\beta$-cell replication in newly diabetic NOD mice," Diabetes, vol. 63, no. 9, pp. 3128-3134, 2014.

[17] J. Tian, H. Dang, and D. L. Kaufman, "Combining antigenbased therapy with GABA treatment synergistically prolongs survival of transplanted $\beta$-cells in diabetic NOD mice," PLoS One, vol. 6, no. 9, article e25337, 2011.

[18] M. Braun, A. Wendt, K. Buschard et al., "GABAB receptor activation inhibits exocytosis in rat pancreatic $\beta$-cells by G-protein-dependent activation of calcineurin," The Journal of Physiology, vol. 559, Part 2, pp. 397-409, 2004.

[19] A. Wendt, B. Birnir, K. Buschard et al., "Glucose inhibition of glucagon secretion from rat alpha-cells is mediated by GABA released from neighboring $\beta$-cells," Diabetes, vol. 53, no. 4 , pp. 1038-1045, 2004.

[20] N. L. Brice, A. Varadi, S. J. Ashcroft, and E. Molnar, "Metabotropic glutamate and $\mathrm{GABA}(\mathrm{B})$ receptors contribute to the modulation of glucose-stimulated insulin secretion in pancreatic beta cells," Diabetologia, vol. 45, no. 2, pp. 242-252, 2002.

[21] S. J. Bailey, M. A. Ravier, and G. A. Rutter, "Glucose-dependent regulation of $\gamma$-aminobutyric acid $\left(\mathrm{GABA}_{\mathrm{A}}\right)$ receptor expression in mouse pancreatic islet $\alpha$-cells," Diabetes, vol. 56, no. 2, pp. 320-327, 2007.

[22] N. Ben-Othman, A. Vieira, M. Courtney et al., "Long-term GABA administration induces alpha cell-mediated beta-like cell neogenesis," Cell, pp. 31523-31529, 2016.

[23] J. Li, T. Casteels, T. Frogne et al., "Artemisinins target GABAA receptor signaling and impair alpha cell identity," Cell, vol. 168, no. 1-2, article e115, pp. 86-100, 2017.

[24] J. Li, Z. Zhang, X. Liu et al., "Study of GABA in healthy volunteers: pharmacokinetics and pharmacodynamics," Frontiers in Pharmacology, vol. 6, p. 260, 2015.

[25] D. B. Tower and E. Roberts, Eds., Inhibition in the nervous system and GABA, pp. 562-578, Pergamon Press, New York, 1960.

[26] A. Lehmann, M. Antonsson, A. A. Holmberg et al., "(R)-(3Amino-2-fluoropropyl) phosphinic acid (AZD3355), a novel $\mathrm{GABAB}$ receptor agonist, inhibits transient lower esophageal sphincter relaxation through a peripheral mode of action," The Journal of Pharmacology and Experimental Therapeutics, vol. 331, no. 2, pp. 504-512, 2009.

[27] N. J. Shaheen, H. Denison, K. Bjorck, M. Karlsson, and D. G. Silberg, "Efficacy and safety of lesogaberan in gastrooesophageal reflux disease: a randomised controlled trial," Gut, vol. 62, no. 9, pp. 1248-1255, 2013.

[28] C. Alstermark, K. Amin, S. R. Dinn et al., "Synthesis and pharmacological evaluation of novel gamma-aminobutyric acid type $B(\mathrm{GABAB})$ receptor agonists as gastroesophageal reflux inhibitors," Journal of Medicinal Chemistry, vol. 51, no. 14, pp. 4315-4320, 2008.

[29] M. Niazi, S. Skrtic, M. Ruth, and A. A. Holmberg, "Pharmacokinetic profile of lesogaberan (AZD3355) in healthy subjects: a novel GABA(B)-receptor agonist reflux inhibitor," Drugs in $R \& D$, vol. 11, no. 1, pp. 77-83, 2011.

[30] B. Fransson, D. G. Silberg, M. Niazi, F. Miller, M. Ruth, and A. A. Holmberg, "Effect of food on the bioavailability of lesogaberan given as an oral solution or as modifiedrelease capsules in healthy male volunteers," International Journal of Clinical Pharmacology and Therapeutics, vol. 50, no. 4, pp. 307-314, 2012.

[31] G. E. Boeckxstaens, H. Beaumont, V. Mertens et al., "Effects of lesogaberan on reflux and lower esophageal sphincter function in patients with gastroesophageal reflux disease," Gastroenterology, vol. 139, no. 2, pp. 409-417, 2010.

[32] G. E. Boeckxstaens, H. Beaumont, J. G. Hatlebakk et al., "A novel reflux inhibitor lesogaberan (AZD3355) as add-on treatment in patients with GORD with persistent reflux symptoms despite proton pump inhibitor therapy: a randomised placebo-controlled trial," Gut, vol. 60, no. 9, pp. 1182 1188, 2011.

[33] M. Niazi, D. G. Silberg, F. Miller, M. Ruth, and A. A. Holmberg, "Evaluation of the pharmacokinetic interaction between lesogaberan (AZD3355) and esomeprazole in healthy subjects," Drugs in R\&D, vol. 10, no. 4, pp. 243-251, 2010.

[34] L. Branden, A. Fredriksson, E. Harring, J. Jensen, and A. Lehmann, "The novel, peripherally restricted GABAB receptor agonist lesogaberan (AZD3355) inhibits acid reflux and reduces esophageal acid exposure as measured with 24-h pHmetry in dogs," European Journal of Pharmacology, vol. 634, no. 1-3, pp. 138-141, 2010.

[35] J. A. Emamaullee and A. M. Shapiro, "Factors influencing the loss of beta-cell mass in islet transplantation," Cell Transplantation, vol. 16, no. 1, pp. 1-8, 2007. 
[36] A. M. Davalli, Y. Ogawa, C. Ricordi, D. W. Scharp, S. BonnerWeir, and G. C. Weir, "A selective decrease in the beta cell mass of human islets transplanted into diabetic nude mice," Transplantation, vol. 59, no. 6, pp. 817-820, 1995.

[37] B. E. Gregg, P. C. Moore, D. Demozay et al., "Formation of a human $\beta$-cell population within pancreatic islets is set early in life," The Journal of Clinical Endocrinology and Metabolism, vol. 97, no. 9, pp. 3197-3206, 2012.

[38] S. Huang, J. Mao, B. Wei, and G. Pei, "The anti-spasticity drug baclofen alleviates collagen-induced arthritis and regulates dendritic cells," Journal of Cellular Physiology, vol. 230, no. 7, pp. 1438-1447, 2015.

[39] B. Duthey, A. Hubner, S. Diehl, S. Boehncke, J. Pfeffer, and W. H. Boehncke, "Anti-inflammatory effects of the GABA(B) receptor agonist baclofen in allergic contact dermatitis," Experimental Dermatology, vol. 19, no. 7, pp. 661-666, 2010. 


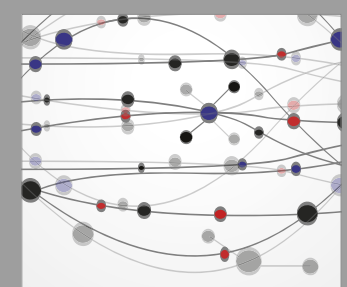

The Scientific World Journal
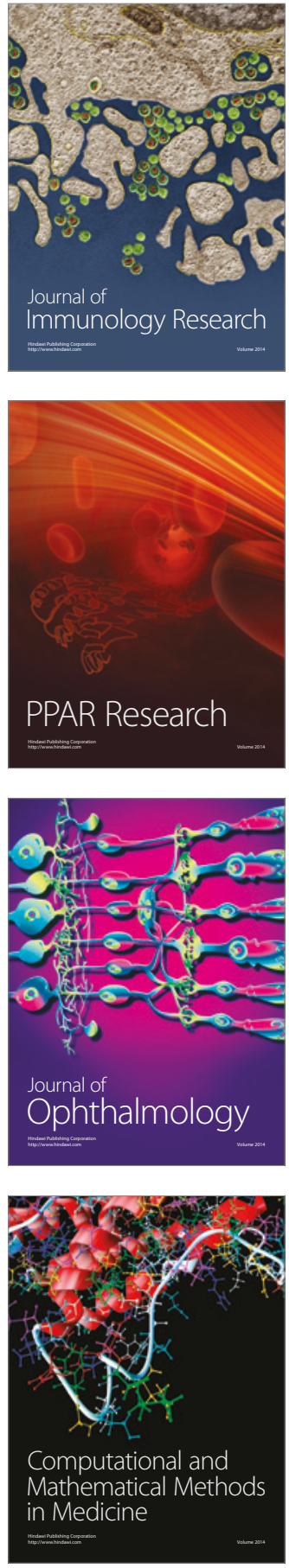

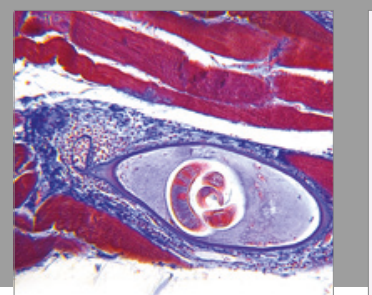

Gastroenterology Research and Practice
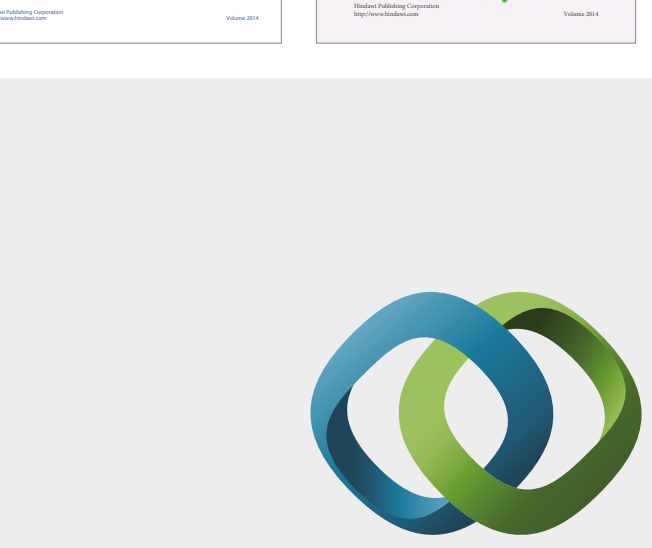

\section{Hindawi}

Submit your manuscripts at

https://www.hindawi.com
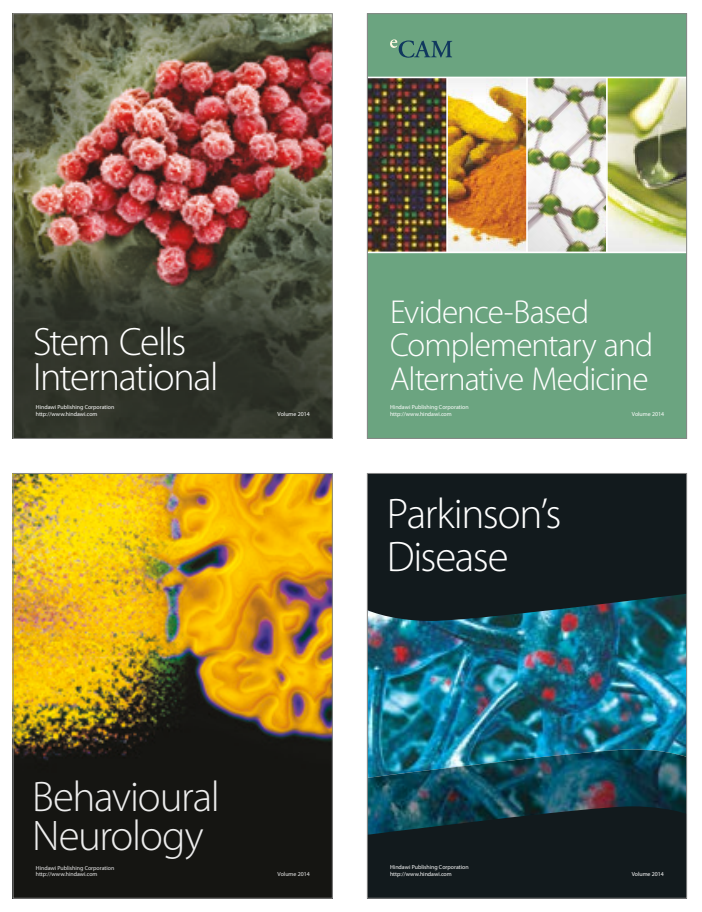
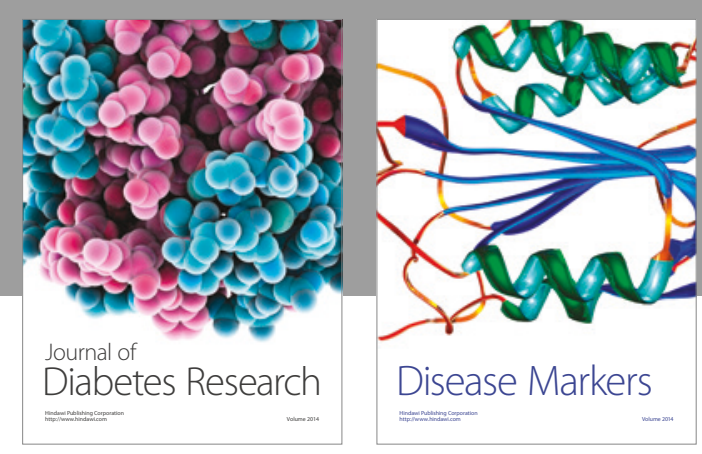

Disease Markers
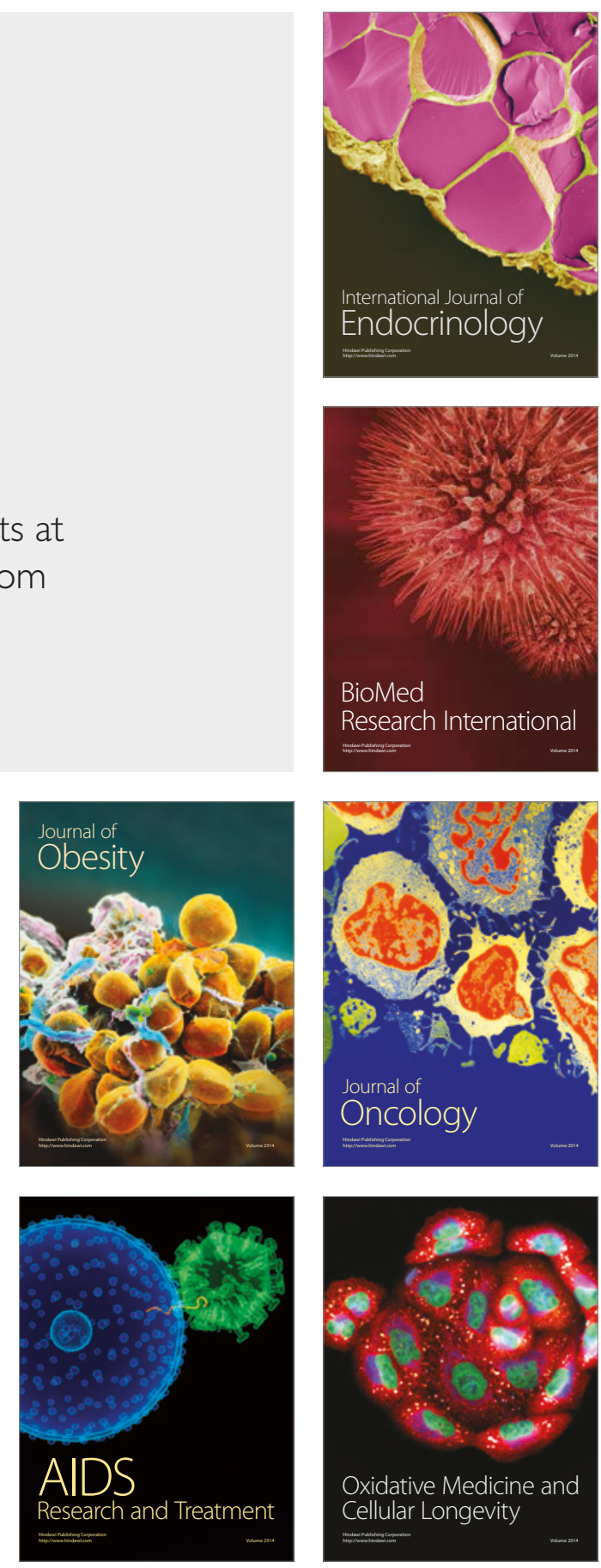